\title{
Erratum to: Carl Christian Tscherning: a scientific adventure in Geodesy
}

Fernando Sansò $^{1} \cdot$ Michael G. Sideris ${ }^{2}$

Published online: 11 August 2015

(C) Springer-Verlag Berlin Heidelberg 2015

\section{Erratum to: J Geod}

\section{DOI 10.1007/s00190-015-0815-3}

In the original publication of the article, the author names and their affiliation were not included. The complete information is provided below:

Fernando Sansò

Politecnico di Milano, Polo Regionale di Como,

Como, Italy

Michael G. Sideris $(\bowtie)$

University of Calgary,

Calgary, AB, Canada

E-mail: sideris@ucalgary.ca

The original publication has been updated accordingly.

The online version of the original article can be found under doi:10.1007/s00190-015-0815-3.

Michael G. Sideris

sideris@ucalgary.ca

1 Politecnico di Milano, Polo Regionale di Como, Como, Italy

2 University of Calgary, Calgary, AB, Canada 